\title{
Reactivating p53 functions by suppressing its novel inhibitor iASPP: a potential therapeutic opportunity in p53 wild-type tumors
}

\author{
Peixin Dong1, Kei Ihira², Junichi Hamada ${ }^{3}$, Hidemichi Watari $^{2}$, Takahiro Yamada ${ }^{1}$, \\ Masayoshi Hosaka², Sharon J.B. Hanley¹, Masataka Kudo² and Noriaki Sakuragi, ${ }^{1,2}$ \\ ${ }^{1}$ Department of Women's Health Educational System, Hokkaido University School of Medicine, Hokkaido University, Sapporo, \\ Japan \\ 2 Department of Gynecology, Hokkaido University School of Medicine, Hokkaido University, Sapporo, Japan \\ ${ }^{3}$ Department of Stem Cell Biology, Hokkaido University Graduate School of Medicine, Kita-Ku, Sapporo, Japan \\ Correspondence to: Peixin Dong, email: dpxlcn@gmail.com
}

Keywords: review, reactivation of p53, iASPP, microRNA, invasion

Received: May 04, $2015 \quad$ Accepted: June 28, $2015 \quad$ Published: July 13, 2015

This is an open-access article distributed under the terms of the Creative Commons Attribution License, which permits unrestricted use, distribution, and reproduction in any medium, provided the original author and source are credited.

\section{ABSTRACT}

Although mutational inactivation of p53 is found in $50 \%$ of all human tumors, a subset of tumors display defective p53 function, but retain wild-type (WT) p53. Here, direct and indirect mechanisms leading to the loss of WT p53 activities are discussed. We summarize the oncogenic roles of IASPP, an inhibitor of WT p53, in promoting proliferation, invasion, drug or radiation-resistance and metastasis. From the therapeutic view, we highlight promising perspectives of microRNA-124, peptide and small molecules that reduce or block iASPP for the treatment of cancer. High iASPP expression enhances proliferation, aggressive behavior, the resistance to radiation/chemotherapy and correlates with poor prognosis in a range of human tumors. Overexpression of iASPP accelerates tumorigenesis and invasion through p53-dependent and p53-independent mechanisms. MicroRNA-124 directly targets iASPP and represses the growth and invasiveness of cancer cells. The disruption of iASPP-p53 interaction by a p53-derived peptide A34 restores p53 function in cancer cells. The inhibition of iASPP phosphorylation with small molecules induces p53dependent apoptosis and growth suppression. The mechanisms underlying aberrant expression of iASPP in human tumors should be further investigated. Reactivating WT p53 functions by targeting its novel inhibitor iASPP holds promise for potential therapeutic interventions in the treatment of WT p53-containing tumors.

\section{INTRODUCTION}

The initiation and progression of cancer is a multistep process including self-renewal, aberrant cell cycle, defective apoptosis, the induction of the epithelial to mesenchymal transition (EMT), enhanced mobility, invasion and angiogenesis, and the remodeling of the tumor microenvironment [1]. In addition to numerous genetic alterations, such as inactivation of a tumor suppressor and activation of an oncogene, human tumor cells harbor global epigenetic abnormalities, such as DNA methylation, histone modifications, nucleosome positioning and non-coding RNAs [2]. Genetic and epigenetic changes interact with each other to enable cancer progression [3].

MicroRNAs (miRNAs) are characterized as endogenous, small size, non-coding RNA molecules that post-transcriptionally control the translation and stability of mRNAs [4]. MiRNAs are predicted to regulate the expression of approximately $60 \%$ of human genes [5]. A single miRNA can bind to multiple mRNAs via perfect or partial base-pairing with the 3 '-untranslated region (UTR) of the target mRNAs [5], resulting in profound effects on gene expression and cellular functions. MiRNAs modulate tumor cell proliferation, invasion and EMT/cancer stem cell (CSC) properties by targeting multiple downstream 
genes or signaling pathways $[6,7,8]$.

The p53 family members (p53, p63 and p73) play a pivotal role in the regulation of many critical biological processes including cell death, proliferation, cell cycle control and tumorigenesis $[9,10,11,12]$. When DNA damage is sensed, the apical kinases ATM and ATR checkpoint pathways are triggered, and in turn activates and stabilizes wild-type (WT) p53 via the phosphorylation of CHK2/CHK1, or degradation of MDM2 [13]. Once activated by various cellular stresses, WT p53 accumulates in the nucleus and works as a transcriptional factor to either transactivate or transrepress downstream genes or miRNAs, leading to the induction of growth arrest, cellular senescence and apoptosis, the inhibition of angiogenesis and metastasis in tumors $[9,14,15,16]$ (Figure 1). In addition to these anticancer effects, a new role of p53 has emerged, regulation of EMT and CSC features $[9,17,18]$. During the metastatic cascade, tumor cells usually activate the EMT, a dynamic cellular process thought to be critical step of metastasis by promoting the acquisition of migratory and invasive capabilities and gain of CSC-like phenotypes, such as the resistance to radiation or chemotherapy [1]. Several transcription factors including Snail, Slug, Twist and ZEB-1/2 induce EMT, by downregulating the epithelial markers such as E-cadherin and by upregulating the mesenchymal markers such as vimentin [1]. By targeting Slug and Snail, p53 negatively regulates EMT and suppresses cancer cell invasiveness $[19,20]$. Emerging evidence has demonstrated that WT p53 can also indirectly silence EMT-inducing transcription factors though the transcriptional regulation of some miRNAs, such as miR-34, miR-130b, miR-145, miR192, miR-215 and miR-200c [21, 22, 23, 24, 25, 26, 27]. For example, by binding to the promoter region of $m i R-130 b, \mathrm{p} 53$ transactivates this miRNA to reduce the levels of ZEB1 (a direct target gene of miR-130b), and thereby attenuates EMT and invasiveness in endometrial cancer cells [22]. These studies support the idea that the disruption of $\mathrm{p} 53$ tumor suppressor-regulated pathways contributes to progression and worse clinical outcome of human tumors [28].

In this review, we provide a brief overview of the mechanisms by which the functions of WT p53 are inactivated and will focus on the oncogenic roles of iASPP, a negative regulator of WT p53, in human tumors. We will discuss current approaches that aim to restore p53 functions by targeting iASPP, including miR-124, a peptide derived from p53 and other small molecules.

\section{DIRECT AND INDIRECT MECHANISMS LEADING TO THE LOSS OF WT P53 ACTIVITIES IN HUMAN TUMORS}

The loss of p53 function in human cancers occurs either by direct or indirect mechanisms (Figure 1a). At least half of all tumors lose WT p53 function as a result of mutations [29], however a subset of tumors, such as cervical cancer, chronic lymphocytic leukaemia, acute lymphoblastic leukaemia, acute myeloblastic leukaemia, myeloma, neuroblastoma, melanoma, mantle cell lymphoma and sarcoma, retains WT p53, but its activity can be attenuated $[30,31]$. MDM2 is the bestknown inhibitor of p53. MDM2 limits p53 activity by binding to and blocking the $\mathrm{N}$-terminal trans-activation domain of p53, or by working as an E3 ubiquitin ligase to promote $\mathrm{p} 53$ degradation [32,33]. MDM2 is directly inhibited by the tumor suppressor p14ARF, loss of which also leads to reduced p53 [34]. MDMX, a homolog of MDM2, can interact with $\mathrm{p} 53$ and repress its activities [35]. Moreover, the EMT inducers Twist and BMI-1 were shown to mediate the inhibition of p53 pathway via suppressing p14ARF $[36,37]$. The E6 oncoproteins of high-risk human papillomaviruses (HPV) bind p53 and are capable of inducing its degradation [38]. Human $T P 73$ gene produces an NH2 terminally truncated isoform, $\Delta \mathrm{Np} 73$ that lacks the transactivation domain and function as a dominant-negative inhibitor of WT p53 [39]. Other mechanisms responsible for loss of WT p53 functions in human tumors include the lack of p53 nuclear retention [40] and the deacetylation of p53 by Sirtuin 1 (SIRT1) [41]. Thus, the reactivation of endogenous $p 53$, either by reducing or blocking its negative regulators, would benefit cancer patients with WT p53 tumors [42].

\section{THE ONCOGENIC ROLES OF IASPP IN HUMAN TUMORS}

To date, intensive efforts have been made to restore WT p53 activity as an anticancer therapeutic approach [42]. Reducing the levels of p53 suppressors or interfering with the direct physical association between p53 suppressors and p53, has shown effectiveness for the restoration of $\mathrm{p} 53$ function. For example, Withaferin A (WA), a small-molecule natural compound, downregulates the expression of HPV E6 oncoprotein and helps to restore p53-dependent apoptosis in cervical cancer cells [43]. Given that the inhibition of $\mathrm{p} 53$ by MDM2 protein relies on their direct binding with $\mathrm{p} 53$, small-molecule MDM2 inhibitors, such as Nutlin-3 that disrupts this interaction, have been utilized to induce WT p53-mediated cell-cycle arrest and apoptosis in various types of tumor cells [42]. However, tumor cells may develop the resistance to Nutlin-3 owing to the fact that this MDM2 inhibitor does not efficiently target the MDMX-p53 interaction or fails to induce MDMX degradation [44]. More importantly, the continuous Nutlin-3 exposure can result in the acquisition of somatic mutations in p53 and select for p53-mutated cells in solid tumors $[45,46]$. Therefore, additional attempts to achieve p53 activation through targeting other p53 inhibitors are required for effective tumor regression.

The ASPP family consisting of three proteins (ASPP1, ASPP2 and iASPP) interacts with and modulates 
the functions of WT p53 [47]. ASPP1/2 enhances p53dependent cell death, whereas iASPP inhibits the apoptotic transactivation potential of p53 by direct interaction [47]. Here, we review the oncogenic functions of iASPP in tumors and discuss promising therapeutic perspectives of miRNA, peptide and small molecules that reduce or block iASPP for the treatment of cancer.

Human iASPP, which is encoded by $P P P 1 R 13 L$ located on 19q13.2-3 [48], has two isoforms (407 and 828 amino acids-aa) $[49,50]$. The shorter form of iASPP (407 aa) is a nuclear protein, and the longer form of iASPP ( 828 aa) is located in both the nucleus and cytoplasm [48, 49, 50]. iASPP was considered as an oncogene that not only inhibits the transcriptional activity of p53 on promoters of downstream genes (Figure 1a), but also promotes carcinogenesis through p53-independent mechanisms, mainly by inhibiting the apoptotic activity of p63 and p73 [51]. Of note, in normal cells, iASPP can actually induce apoptosis via inhibition of nuclear factor- $\kappa \mathrm{B}(\mathrm{NF}-\kappa \mathrm{B})$ [52].

iASPP is overexpressed in diverse human tumors, including colorectal cancer [53], acute leukemia [54], endometrioid endometrial cancer [55], lung cancer [56], glioblastoma [57], head and neck squamous cell carcinoma [58], prostate cancer [59], hepatocellular carcinoma $[60,61,62]$, oral squamous cell carcinoma [63, 64], cervical cancer [65] and ovarian cancer [66]. Elevated expression of iASPP correlates with poor survival in head and neck cancer [58], oral squamous cell carcinoma [64], cervical cancer [65] and ovarian cancer [66]. Increased iASPP expression is associated with tumor grade, invasion and lymph node metastasis in endometrial cancer [55]. Furthermore, siRNA- or shRNA-mediated iASPP silencing reduces in vitro proliferation in human cancer cells [56, 59, 60, 61, 62, 63, 67, 68, 69]. The overexpression of iASPP in primary mouse embryonic fibroblasts promotes p53 degradation and strongly stimulates cell migration and metastasis [70]. These data suggest that iASPP contributes to the progression and metastasis of human tumors.

Human cancers are composed of heterogeneous cell populations. Genetic and phenotypic variation exists not only between different tumor types or between patients with the same tumor type (inter-tumor heterogeneity), but

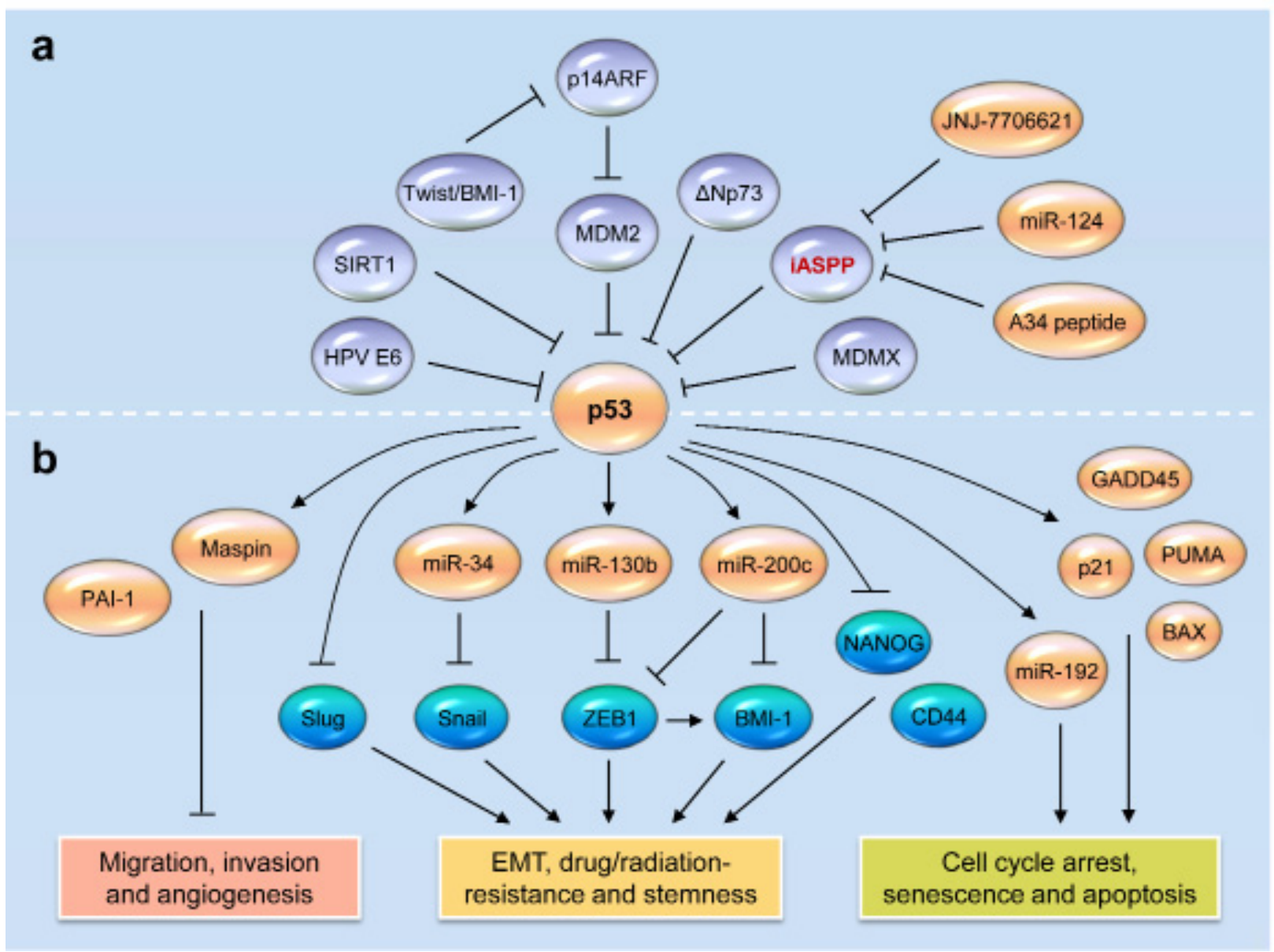

Figure 1: Reactivating wild-type p53 functions in tumors by targeting its novel inhibitor iASPP. a. Direct and indirect mechanisms of p53 inactivation in human tumors. iASPP acts as a key p53 inhibitor. MiR-124 negatively regulates the expression of iASPP in human tumors. The disruption of iASPP-p53 interaction by a p53-derived peptide A34 restores p53 function in cancer cells. The inhibition of iASPP phosphorylation with small molecule JNJ-7706621 induces p53-dependent apoptosis and growth suppression. b. Wildtype p53 represses cancer initiation, progression and metastasis by regulating downstream genes and microRNAs (miR-34, miR-130b, miR-192 and miR-200c)-target gene networks. 
also within a single tumor (intra-tumor heterogeneity) [71]. This intra-tumor heterogeneity produces distinct subclones that show diverse malignant properties [72.]. It is thought that within a tumor, only a small population of tumor cells (CSC) is capable of self-renewal, multipotency, in vivo tumorigenicity and forming metastasis $[73,74]$. This CSC model has been used to explain tumor heterogeneity. Accumulating evidence has linked p53 loss to stem-like phenotypes in cancers [9]. Importantly, knockdown of iASPP with siRNA impaired in vivo tumorigenesis of prostate cancer cells [59]. These data support the possible role of iASPP in promoting CSC properties, at least though inhibiting p53 activity.

On the other hand, the concept of CSC plasticity (the model of dynamic stemness) has been also proposed [75], in which CSC and non-CSC states may not be definitive, and cancer cells have the dynamic and transient ability of shifting from a non-CSC state to a CSC state as a consequence of EMT induction or microenvironmental stimuli [75]. The plasticity of CSC may at least partially help explain the tumor heterogeneity observed in tumors, and is consistent with those findings that tumor cell undergoing EMT can acquire stem cell-like properties [1].

Despite some results showing that the activation of EMT program suppresses the tumor-initiating properties of CSCs $[76,77]$, numerous studies have provided a strong link between EMT activation and the emergence of a CSClike phenotype in human cancers [78]. In endometrial cancer, oncogenes such as $p 53$ gain-of-function mutations [21], KLF17 [79], EZH2, MCL-1 and FOS [8] promote EMT-associated invasiveness and enhance CSC properties including self-renewal capacity and chemoresistance, whereas miR-101, miR-106b, miR-130b and miR-194 [7, $8,22,80]$ serve as EMT suppressors and attenuate CSC features. Of significance, CSC cells enriched with CD29 and CD44 markers exhibit molecular characteristics, consistent with EMT [81]. These data collectively suggest a close correlation between EMT induction and CSC characteristics.

The increased iASPP expression is correlated with the resistance to radiation or chemotherapy in cervical cancer [65]. The overexpression of iASPP in ovarian cancer cells confers resistance to paclitaxel [66]. Consistent with these observations, enhanced iASPP expression can render cells resistant to ultraviolet radiation and cisplatin-induced apoptosis in human tumors expressing WT p53 [82]. Given the anti-oncogenic effects of WT p53 on EMT and CSC phenotypes, we speculate that iASPP might have a regulatory role in enhancing EMT and CSC-related phenotypes, such as resistance to chemotherapy and radiation, by inhibiting WT p53 function [83]. More studies are clearly needed to address these possibilities.

\section{IASPP, A TARGET FOR ANTITUMOR THERAPEUTICS}

The therapeutic targeting of iASPP might include targeting iASPP itself as well as modulating its upstream regulators or downstream effectors (Figure 1a). The Wnt/ beta-catenin signaling seems to be an upstream regulator of iASPP in gastric cancer, because the attenuation of beta-catenin by shRNA resulted in apparent apoptosis and downregulated iASPP [84]. MiR-124 directly targets $i A S P P$ and represses the growth and invasiveness in a variety of cancer cells, including colorectal cancer, glioblastoma and prostate cancer [85, 86, 87]. In addition, A34 (a small peptide derived from p53 linker) binds directly to iASPP and competitively inhibits the iASPP-p53 interaction in human tumor cells [88], causing WT p53-mediated transcriptional activation of Bax and PUMA and tumor cell apoptosis in vitro and in vivo [88]. Furthermore, a small-molecule inhibitor of cyclin B/ CDK1, JNJ-7706621 that inhibits iASPP phosphorylation and prevents the nuclear entry of iASPP, can induce WT p53-dependent apoptosis and growth suppression in melanoma cells [89]. The identification of miRNAs and molecules that control the levels of iASPP and a high-throughput screening to search for small-molecule compounds that release p53 from iASPP, would lead to the development of therapies against iASPP for the treatment of human tumors through activation of WT p53.

\section{CONCLUSIONS}

In addition to affecting tumor cell proliferation and survival, WT p53 can repress cancer initiation, progression and metastasis by regulating downstream genes and miRNAs-target gene networks. A more complete understanding of genetic and epigenetic mechanisms underlying aberrant expression of WT p53 inhibitor iASPP in human tumors, and detailed studies on iASPP function in various aspects of tumor progression, including EMT, stemness and metastasis, can provide a basis for new potential therapeutic applications in WT p53-containing tumors.

\section{ACKNOWLEDGMENTS}

This work was funded by a grant from the Department of Women's Health Educational System, a Grant-in-Aid for Scientific Research (C) (15K10697; 24592497; 24592496) and a Grant-in-Aid for Challenging Exploratory Research (25670690). We thank Dr. Zhujie $\mathrm{Xu}$ for help in preparing figure.

\section{CONFLICTS OF INTEREST}

The authors declare no competing financial interests. 


\section{Authors' contributions}

Peixin Dong and Kei Ihira wrote the manuscript. Junichi Hamada, Hidemichi Watari, Takahiro Yamada, Masayoshi Hosaka, Sharon JB Hanley, Masataka Kudo and Noriaki Sakuragi assisted with manuscript revisions. All authors discussed the content and approved the final version of manuscript.

\section{REFERENCES}

1. Hanahan D, Weinberg RA. Hallmarks of Cancer: The Next Generation. Cell. 2011; 144: 646-674.

2. Sharma S, Kelly TK, Jones PA. Epigenetics in cancer. Carcinogenesis. 2010; 31: 27-36.

3. Wang X, Jin H. The epigenetic basis of the Warburg effect. Epigenetics. 2010; 5: 566-568.

4. Bartel DP. MicroRNAs: genomics, biogenesis, mechanism, and function. Cell. 2004; 116: 281-297.

5. Friedman RC, Farh KK, Burge CB, Bartel DP. Most mammalian mRNAs are conserved targets of microRNAs. Genome Res. 2009; 19: 92-105.

6. Dong P, Konno Y, Watari H, Hosaka M, Noguchi M, Sakuragi N. The impact of microRNA-mediated PI3K/AKT signaling on epithelial-mesenchymal transition and cancer stemness in endometrial cancer. J Transl Med. 2014; 12: 231-240.

7. Dong P, Kaneuchi M, Watari H, Hamada J, Sudo S, Ju J, Sakuragi N. MicroRNA-194 inhibits epithelial to mesenchymal transition of endometrial cancer cells by targeting oncogene BMI-1. Mol Cancer. 2011; 10: 9-108.

8. Konno Y, Dong P, Xiong Y, Suzuki F, Lu J, Cai M, Watari H, Mitamura T, Hosaka M, Hanley SJ, Kudo M, Sakuragi N. MicroRNA-101 targets EZH2, MCL-1 and FOS to suppress proliferation, invasion and stem celllike phenotype of aggressive endometrial cancer cells. Oncotarget. 2014; 5: 6049-6062.

9. Bieging KT, Mello SS, Attardi LD. Unravelling mechanisms of p53-mediated tumour suppression. Nat Rev Cancer. 2014; 14: 359-370.

10. Pietsch EC, Sykes SM, McMahon SB, Murphy ME. The p53 family and programmed cell death. Oncogene. 2008; 27: 6507-6521.

11. Su X, Chakravarti D, Cho MS, Liu L, Gi YJ, Lin YL, Leung ML, El-Naggar A, Creighton CJ, Suraokar MB, Wistuba I, Flores ER. TAp63 suppresses metastasis through coordinate regulation of Dicer and miRNAs. Nature. 2010; 467: 986990.

12. Melino G, De Laurenzi V, Vousden KH. p73: Friend or foe in tumorigenesis. Nat Rev Cancer. 2002; 2: 605-615.

13. Christmann M, Kaina B. Transcriptional regulation of human DNA repair genes following genotoxic stress: trigger mechanisms, inducible responses and genotoxic adaptation. Nucleic Acids Res. 2013; 41: 8403-8420.

14. Sugrue MM, Shin DY, Lee SW, Aaronson SA. Wild-type p53 triggers a rapid senescence program in human tumor cells lacking functional p53. Proc Natl Acad Sci U S A. 1997; 94: 9648-9653.

15. Zou Z, Gao C, Nagaich AK, Connell T, Saito S, Moul JW, Seth P, Appella E, Srivastava S. p53 regulates the expression of the tumor suppressor gene maspin. J Biol Chem. 2000; 275: 6051-6054.

16. Shetty S, Shetty P, Idell S, Velusamy T, Bhandary YP, Shetty RS. Regulation of plasminogen activator inhibitor-1 expression by tumor suppressor protein p53. J Biol Chem. 2008; 283: 19570-19580.

17. Lin T, Chao C, Saito S, Mazur SJ, Murphy ME, Appella E, $\mathrm{Xu}$ Y. p53 binds to the promoter of Nanog, a gene required for ESC self-renewal, and suppresses Nanog expression after DNA damage. Nat Cell Biol. 2005; 7: 165-171.

18. Godar S, Ince TA, Bell GW, Feldser D, Donaher JL, Bergh J, Liu A, Miu K, Watnick RS, Reinhardt F, McAllister SS, Jacks T, Weinberg RA. Growth-inhibitory and tumorsuppressive functions of p53 depend on its repression of CD44 expression. Cell. 2008; 134: 62-73.

19. Lim SO, Kim H, Jung G. p53 inhibits tumor cell invasion via the degradation of snail protein in hepatocellular carcinoma. FEBS Lett. 2010; 584: 2231-2236.

20. Wang SP, Wang WL, Chang YL, Wu CT, Chao YC, Kao SH, Yuan A, Lin CW, Yang SC, Chan WK, Li KC, Hong TM, Yang PC. p53 controls cancer cell invasion by inducing the MDM2-mediated degradation of Slug. Nat Cell Biol. 2009; 11: 694-704.

21. Corney DC, Flesken-Nikitin A, Godwin AK, Wang W, Nikitin AY. MicroRNA-34b and MicroRNA-34c are targets of p53 and cooperate in control of cell proliferation and adhesion-independent growth. Cancer Res. 2007; 67: 84338438 .

22. Dong P, Karaayvaz M, Jia N, Kaneuchi M, Hamada J, Watari H, Sudo S, Ju J, Sakuragi N. Mutant p53 gain-offunction induces epithelial-mesenchymal transition through modulation of the miR-130b-ZEB1 axis. Oncogene. 2013; 32: 3286-3295.

23. Sachdeva M, Zhu S, Wu F, Wu H, Walia V, Kumar S, Elble R, Watabe K, Mo YY. p53 represses c-Myc through induction of the tumor suppressor miR-145. Proc Natl Acad Sci U S A. 2009; 106: 3207-3212.

24. Suzuki HI, Yamagata K, Sugimoto K, Iwamoto T, Kato S, Miyazono K. Modulation of microRNA processing by $\mathrm{p} 53$. Nature. 2009; 460: 529-533.

25. Song B, Wang Y, Kudo K, Gavin EJ, Xi Y, Ju J. miR-192 Regulates dihydrofolate reductase and cellular proliferation through the p53-microRNA circuit. Clin Cancer Res. 2008; 14: 8080-8086.

26. Braun CJ, Zhang X, Savelyeva I, Wolff S, Moll UM, Schepeler T, Ørntoft TF, Andersen CL, Dobbelstein M. p53-Responsive micrornas 192 and 215 are capable of 
inducing cell cycle arrest. Cancer Res. 2008; 68: $10094-$ 10104.

27. Chang CJ, Chao CH, Xia W, Yang JY, Xiong Y, Li CW, Yu WH, Rehman SK, Hsu JL, Lee HH, Liu M, Chen CT, Yu D, Hung MC. p53 regulates epithelial-mesenchymal transition and stem cell properties through modulating miRNAs. Nat Cell Biol. 2011; 13: 317-323.

28. Powell E, Piwnica-Worms D, Piwnica-Worms H. Contribution of p53 to Metastasis. Cancer Discov. 2014; 4: 405-414.

29. Olivier M, Hollstein M, Hainaut P. TP53 mutations in human cancers: origins, consequences, and clinical use. Cold Spring Harb Perspect Biol. 2010; 2: a001008-001025.

30. Barone G, Tweddle DA, Shohet JM, Chesler L, Moreno L, Pearson AD, Van Maerken T. MDM2-p53 interaction in paediatric solid tumours: preclinical rationale, biomarkers and resistance. Curr Drug Targets. 2014; 15: 114-123

31. Khoo KH, Verma CS, Lane DP. Drugging the p53 pathway: understanding the route to clinical efficacy. Nat Rev Drug Discov. 2014; 13: 217-236.

32. Montes de Oca Luna R, Wagner DS, Lozano G. Rescue of early embryonic lethality in mdm2-deficient mice by deletion of p53. Nature. 1995; 378: 203-206.

33. Haupt Y, Maya R, Kazaz A, Oren M. Mdm2 promotes the rapid degradation of p53. Nature. 1997; 387: 296-299.

34. Sherr CJ. Divorcing ARF and p53: an unsettled case. Nat Rev Cancer. 2006; 6: 663-673.

35. Dotto GP. Crosstalk of Notch with p53 and p63 in cancer growth control. Nat Rev Cancer. 2009; 9: 587-595.

36. Valsesia-Wittmann S, Magdeleine M, Dupasquier S, Garin E, Jallas AC, Combaret V, Krause A, Leissner P, Puisieux A. Oncogenic cooperation between H-Twist and N-Myc overrides failsafe programs in cancer cells. Cancer Cell. 2004; 6:625-630.

37. Bracken AP, Kleine-Kohlbrecher D, Dietrich N, Pasini D, Gargiulo G, Beekman C, Theilgaard-Mönch K, Minucci S, Porse BT, Marine JC, Hansen KH, Helin K. The Polycomb group proteins bind throughout the INK4A-ARF locus and are disassociated in senescent cells. Genes Dev. 2007; 21: 525-530.

38. Scheffner M, Werness BA, Huibregtse JM, Levine AJ, Howley PM. The E6 oncoprotein encoded by human papillomavirus types 16 and 18 promotes the degradation of p53. Cell. 1990; 63: 1129-1136.

39. Zaika AI, Slade N, Erster SH, Sansome C, Joseph TW, Pearl M, Chalas E, Moll UM. DeltaNp73, a dominant-negative inhibitor of wild-type p53 and TAp73, is up-regulated in human tumors. J Exp Med. 2002; 196: 765-780.

40. Moll UM, LaQuaglia M, Bénard J, Riou G. Wild-type p53 protein undergoes cytoplasmic sequestration in undifferentiated neuroblastomas but not in differentiated tumors. Proc Natl Acad Sci U S A. 1995; 92: 4407-4411.

41. Vaziri H, Dessain SK, Ng Eaton E, Imai SI, Frye RA, Pandita TK, Guarente L, Weinberg RA. hSIR2(SIRT1) functions as an NAD-dependent p53 deacetylase. Cell. 2001; 107: 149-159.

42. Wang Z, Sun Y. Targeting p53 for Novel Anticancer Therapy. Transl Oncol. 2010; 3: 1-12.

43. Munagala R, Kausar H, Munjal C, Gupta RC. Withaferin A induces p53-dependent apoptosis by repression of HPV oncogenes and upregulation of tumor suppressor proteins in human cervical cancer cells. Carcinogenesis. 2011; 32: 1697-1705.

44. Shangary S, Wang S. Small-molecule inhibitors of the MDM2-p53 protein-protein interaction to reactivate p53 function: a novel approach for cancer therapy. Annu Rev Pharmacol Toxicol. 2009; 49: 223-241.

45. Michaelis M, Rothweiler F, Barth S, Cinatl J, van Rikxoort M, Löschmann N, Voges Y, Breitling R, von Deimling A, Rödel F, Weber K, Fehse B, Mack E, Stiewe T, Doerr HW, Speidel D, Cinatl J Jr. Adaptation of cancer cells from different entities to the MDM2 inhibitor nutlin-3 results in the emergence of p53-mutated multi-drug-resistant cancer cells. Cell Death Dis. 2011; 2: e243-251.

46. Aziz MH, Shen H, Maki CG. Acquisition of p53 mutations in response to the non-genotoxic p53 activator Nutlin-3. Oncogene. 2011; 30: 4678-4686.

47. Sullivan A, Lu X. ASPP: a new family of oncogenes and tumour suppressor genes. Br J Cancer. 2007; 96: 196-200.

48. Slee EA, Gillotin S, Bergamaschi D, Royer C, Llanos S, Ali S, Jin B, Trigiante G, Lu X. The N-terminus of a novel isoform of human iASPP is required for its cytoplasmic localization. Oncogene. 2004; 23: 9007-9016.

49. Bell HS, Ryan KM. iASPP Inhibition: Increased Options in Targeting the p53 Family for Cancer Therapy. Cancer Res. 2008; 68: 4959-4962.

50. Lu M, Miller P, Lu X. Restoring the tumour suppressive function of p53 as a parallel strategy in melanoma therapy. FEBS Lett. 2014; 588: 2616-2621.

51. Cai Y, Qiu S, Gao X, Gu SZ, Liu ZJ. iASPP inhibits p53independent apoptosis by inhibiting transcriptional activity of p63/p73 on promoters of proapoptotic genes. Apoptosis. 2012; 17: 777-783.

52. Laska MJ, Strandbygård D, Kjeldgaard A, Mains M, Corydon TJ, Memon AA, Sørensen BS, Vogel U, Jensen $\mathrm{UB}, \mathrm{Nex} \varnothing \mathrm{BA}$. Expression of the RAI gene is conducive to apoptosis: studies of induction and interference. Exp Cell Res. 2007; 313:2611-2621.

53. Saebø M, Skjelbred CF, Nexø BA, Wallin H, Hansteen IL, Vogel U, Kure EH. Increased mRNA expression levels of ERCC1, OGG1 and RAI in colorectal adenomas and carcinomas. BMC Cancer. 2006; 6: 208-215.

54. Zhang X, Wang $\mathrm{M}$, Zhou $\mathrm{C}$, Chen S, Wang J. The expression of iASPP in acute leukemias. Leuk Res. 2005; 29: 179-183.

55. Liu WK, Jiang XY, Ren JK, Zhang ZX. Expression pattern of the ASPP family members in endometrial endometrioid adenocarcinoma. Onkologie. 2010; 33: 500-503. 
56. Chen J, Xie F, Zhang L, Jiang WG. iASPP is over-expressed in human non-small cell lung cancer and regulates the proliferation of lung cancer cells through a p53 associated pathway. BMC Cancer. 2010; 10: 694-670.

57. Li G, Wang R, Gao J, Deng K, Wei J, Wei Y. RNA interference-mediated silencing of iASPP induces cell proliferation inhibition and G0/G1 cell cycle arrest in U251 human glioblastoma cells. Mol Cell Biochem. 2011; 350: 193-200.

58. Liu Z, Zhang X, Huang D, Liu Y, Zhang X, Liu L, Li G, Dai Y, Tan H, Xiao J, Tian Y. Elevated expression of iASPP in head and neck squamous cell carcinoma and its clinical significance. Med Oncol. 2012; 29: 3381-3388.

59. Zhang B, Xiao HJ, Chen J, Tao X, Cai LH. Inhibitory member of the apoptosis-stimulating protein of p53 (ASPP) family promotes growth and tumorigenesis in human p53deficient prostate cancer cells. Prostate Cancer Prostatic Dis. 2011; 14: 219-224.

60. Pang MS, Chen X, Lu B, Zhao J, Li BH, Wei YQ, Guo YJ. Lentiviral vector-mediated doxycycline-inducible iASPP gene targeted RNA interference in hepatocellular carcinoma. Chin J Cancer. 2010; 29: 796-801.

61. Lu B, Guo H, Zhao J, Wang C, Wu G, Pang M, Tong X, Bu F, Liang A, Hou S, Fan X, Dai J, Wang H, Guo Y. Increased expression of iASPP, regulated by hepatitis $\mathrm{B}$ virus $\mathrm{X}$ protein-mediated NF- $\mathrm{B}$ activation, in hepatocellular carcinoma. Gastroenterology. 2010; 139: 2183-2194.

62. Lin BL, Xie DY, Xie SB, Xie JQ, Zhang XH, Zhang YF, Gao ZL. Down-regulation of iASPP in human hepatocellular carcinoma cells inhibits cell proliferation and tumor growth. Neoplasma. 2011; 58: 205-210.

63. Chen Y, Yan W, He S, Chen J, Chen D, Zhang Z, Liu Z, Ding $X$, Wang A. In vitro effect of iASPP on cell growth of oral tongue squamous cell carcinoma. Chin J Cancer Res. 2014; 26: 382-390.

64. Kim JW, Roh JL, Park Y, Cho KJ, Choi SH, Nam SY, Kim SY. Cytoplasmic iASPP expression as a novel prognostic indicator in oral cavity squamous cell carcinoma. Ann Surg Oncol. 2015; 22: 662-669.

65. Cao L, Huang Q, He J, Lu J, Xiong Y. Elevated expression of iASPP correlates with poor prognosis and chemoresistance/radioresistance in FIGO Ib1-IIa squamous cell cervical cancer. Cell Tissue Res. 2013; 352: 361-369.

66. Jiang L, Siu MK, Wong OG, Tam KF, Lu X, Lam EW, Ngan HY, Le XF, Wong ES, Monteiro LJ, Chan HY, Cheung AN. iASPP and chemoresistance in ovarian cancers: effects on paclitaxel-mediated mitotic catastrophe. Clin Cancer Res. 2011; 17: 6924-6933.

67. Liu T, Li L, Yang W, Jia H, Xu M, Bi J, Li Z, Liu X, Li Z, Jing H, Kong C. iASPP is important for bladder cancer cell proliferation. Oncol Res. 2011; 19: 125-130.

68. Liu ZJ, Cai Y, Hou L, Gao X, Xin HM, Lu X, Zhong S, $\mathrm{Gu}$ SZ, Chen J. Effect of RNA interference of iASPP on the apoptosis in MCF-7 breast cancer cells. Cancer Invest.
2008; 26: 878-882.

69. Liu H, Wang M, Diao S, Rao Q, Zhang X, Xing H, Wang J. siRNA-mediated down-regulation of iASPP promotes apoptosis induced by etoposide and daunorubicin in leukemia cells expressing wild-type p53. Leuk Res. 2009; 33: 1243-1248.

70. Laska MJ, Lowe SW, Zender L, Hearn S, Vogel U, Jensen UB, Bric A, Nexø BA. Enforced expression of PPP1R13L increases tumorigenesis and invasion through p53-dependent and p53-independent mechanisms. Mol Carcinog. 2009; 48: 832-842.

71. Burrell RA, McGranahan N, Bartek J, Swanton C. The causes and consequences of genetic heterogeneity in cancer evolution. Nature. 2013; 501:338-345.

72. Marusyk A, Almendro V, Polyak K. Intra-tumour heterogeneity: a looking glass for cancer? Nat Rev Cancer. 2012; 12: 323-334.

73. Rybak AP, Bristow RG, Kapoor A. Prostate cancer stem cells: deciphering the origins and pathways involved in prostate tumorigenesis and aggression. Oncotarget. 2015; 6: 1900-1919.

74. Shackleton M, Quintana E, Fearon ER, Morrison SJ. Heterogeneity in cancer: cancer stem cells versus clonal evolution. Cell. 2009; 138: 822-829.

75. Cabrera MC, Hollingsworth RE, Hurt EM. Cancer stem cell plasticity and tumor hierarchy. World J Stem Cells. 2015; 7: 27-36.

76. Celià-Terrassa T1, Meca-Cortés O, Mateo F, de Paz AM, Rubio N, Arnal-Estapé A, Ell BJ, Bermudo R, Díaz A, Guerra-Rebollo M, Lozano JJ, Estarás C, Ulloa C, ÁlvarezSimón D, Milà J, Vilella R, Paciucci R, Martínez-Balbás M, de Herreros AG, Gomis RR, Kang Y, Blanco J, Fernández PL, Thomson TM. Epithelial-mesenchymal transition can suppress major attributes of human epithelial tumorinitiating cells. J Clin Invest. 2012; 122: 1849-1868.

77. Ocaña $\mathrm{OH}$, Córcoles R, Fabra A, Moreno-Bueno G, Acloque H, Vega S, Barrallo-Gimeno A, Cano A, Nieto MA. Metastatic colonization requires the repression of the epithelial-mesenchymal transition inducer Prrx1. Cancer Cell. 2012; 22: 709-724.

78. Singh A, Settleman J. EMT, cancer stem cells and drug resistance: an emerging axis of evil in the war on cancer. Oncogene. 2010; 29: 4741-4751.

79. Dong P, Kaneuchi M, Xiong Y, Cao L, Cai M, Liu X, Guo SW, Ju J, Jia N, Konno Y, Watari H, Hosaka M, Sudo S, Sakuragi N. Identification of KLF17 as a novel epithelial to mesenchymal transition inducer via direct activation of TWIST1 in endometrioid endometrial cancer. Carcinogenesis. 2014; 35: 760-768.

80. Dong P, Kaneuchi M, Watari H, Sudo S, Sakuragi N. MicroRNA-106b modulates epithelial-mesenchymal transition by targeting TWIST1 in invasive endometrial cancer cell lines. Mol Carcinog. 2014; 53: 349-359.

81. Geng S, Guo Y, Wang Q, Li L, Wang J. Cancer stem- 
like cells enriched with CD29 and CD44 markers exhibit molecular characteristics with epithelial-mesenchymal transition in squamous cell carcinoma. Arch Dermatol Res. 2013; 305: 35-47.

82. Bergamaschi D1, Samuels Y, O’Neil NJ, Trigiante G, Crook T, Hsieh JK, O'Connor DJ, Zhong S, Campargue I, Tomlinson ML, Kuwabara PE, Lu X. iASPP oncoprotein is a key inhibitor of $\mathrm{p} 53$ conserved from worm to human. Nat Genet. 2003; 33: 162-167.

83. Jia Y, Peng L, Rao Q, Xing H, Huai L, Yu P, Chen Y, Wang C, Wang M, Mi Y, Wang J. Oncogene iASPP enhances self-renewal of hematopoietic stem cells and facilitates their resistance to chemotherapy and irradiation. FASEB J. 2014; 28: 2816-2827.

84. Jiang H, Xia J, Kang J, Ding Y, Wu W. Short hairpin RNA targeting beta-catenin suppresses cell proliferation and induces apoptosis in human gastric carcinoma cells. Scand J Gastroenterol. 2009; 44: 1452-1462.

85. Liu K, Zhao H, Yao H, Lei S, Lei Z, Li T, Qi H. MicroRNA-124 regulates the proliferation of colorectal cancer cells by targeting iASPP. Biomed Res Int. 2013; 2013: 867537-867548.

86. Zhao WH, Wu SQ, Zhang YD.Downregulation of miR-124 promotes the growth and invasiveness of glioblastoma cells involving upregulation of PPP1R13L. Int J Mol Med. 2013; 32: 101-107.

87. Chen J, Xiao H, Huang Z, Hu Z, Qi T, Zhang B, Tao X, Liu $\mathrm{SH}$. MicroRNA124 regulate cell growth of prostate cancer cells by targeting iASPP. Int J Clin Exp Pathol. 2014; 7: 2283-2290.

88. Qiu S, Cai Y, Gao X, Gu SZ, Liu ZJ. A small peptide derived from p53 linker region can resume the apoptotic activity of p53 by sequestering iASPP with p53. Cancer Lett. 2015; 356: 910-917.

89. Lu M, Breyssens H, Salter V, Zhong S, Hu Y, Baer C, Ratnayaka I, Sullivan A, Brown NR, Endicott J, Knapp S, Kessler BM, Middleton MR, Siebold C, Jones EY, Sviderskaya EV, Cebon J, John T, Caballero OL, Goding $\mathrm{CR}, \mathrm{Lu} \mathrm{X}$. Restoring p53 function in human melanoma cells by inhibiting MDM2 and cyclin B1/CDK1-phosphorylated nuclear iASPP. Cancer Cell. 2013; 23: 618-633. 